\title{
Études/Inuit/Studies
}

\section{Revue des revues Survey of periodicals}

Volume 29, numéro 1-2, 2005

Préserver la langue et les savoirs

Preserving language and knowledge

URI : https://id.erudit.org/iderudit/013961ar

DOI : https://doi.org/10.7202/013961ar

Aller au sommaire du numéro

Éditeur(s)

Association Inuksiutiit Katimajiit Inc.

Centre interuniversitaire d'études et de recherches autochtones (CIÉRA)

ISSN

0701-1008 (imprimé)

1708-5268 (numérique)

Découvrir la revue

Citer ce document

(2005). Revue des revues. Études/Inuit/Studies, 29(1-2), 379-386.

https://doi.org/10.7202/013961ar d'utilisation que vous pouvez consulter en ligne.

https://apropos.erudit.org/fr/usagers/politique-dutilisation/ 


\section{Revue des revues / Survey of periodicals}

\section{Anthropologie / Anthropology}

BERGÉ, Joanna

2003 Le Nunavut et l'espace-monde, contacts culturels et genèse d'une urbanité; Mondialisation / Metropolisation, Geographie et cultures, (48): 101-120.

SALADIN D'ANGLURE, Bernard

2004 Mauss et l'anthropologie des Inuit, Sociologie et société, 36(2): 91-130.

DARNELL, Regna

2005 Obituaries: Frederica de Laguna (1906-2004), American Anthropologist, 107(3): 554-557.

DORAIS, Louis-Jacques

2005 Comparing academic and aboriginal definitions of Arctic identities, Polar Record, 41(216): 1-10.

DOUBLEDAY, N., A.F. MACKENZIE, S. DALBY

2004 Reimagining sustainable cultures: constitutions, land and art, Canadian Geographer-Geographe Canadien, 48(4): 389-402.

DRISCOLL-ENGELSTAD, Bernadette

2005, Dance of the loon: Symbolism and continuity in Copper Inuit ceremonial clothing, Arctic Anthropology, 42(1): 33-46.

GOMBAY, Nicole

2005 Shifting identities in a shifting world: food, place, community, and the politics of scale in an Inuit settlement, Environment and Planning D-Society \& Space, 23(3): 415-433.

HIK, D.S.

2005 IPY 2007-08 and the resurgence of northern (\& polar) research in Canada, Arctic, 58(1): 98-99.

HUHNDORF, Shari

2003 Atanarjuat, The Fast Runner: Culture, History, and Politics in Inuit Media, American Anthropologist, 105(4): 822-827. 
KISHIGAMI, Nobuhiro

2004 A new typology of food-sharing practices among hunter-gatherers, with a special focus on Inuit examples, Journal of Anthropological Research, 60(3): 341-358.

KOROTAYEV, Andrey, Alexander KAZANKOV, Svetlana BORINSKAYA

2004 Ethnographic Atlas XXX: Peoples of Siberia, Ethnology, 43(1): 83-92.

KRUPNIK, Igor, Michael BRAVO, Yvon CSONKA, G. HOVELSRUD-BRODA, Ludger MÜLLER-WILLE, Birger POPPEL, Peter SCHWEITZER, S. SÖRLIN

2005 Social sciences and humanities in the International Polar Year 2007-2008: an integrating mission, Arctic, 58(1): 91-97.

MERBS, Charles F.

2004 Sagittal Clefting of the Body and Other Vertebral Developmental Errors in Canadian Inuit Skeletons, American Journal of Physical Anthropology, 123(3): 236-49.

SEJERSEN, Frank

2004 Horizons of sustainability in Greenland: Inuit landscapes of memory and vision, Arctic Anthropology, 41(1): 71-89.

WENZEL, George W.

2004 From TEK to IQ: Inuit Qaujimajatuqangit and Inuit cultural ecology, Arctic Anthropology, 41(2): 238-250.

\section{Archéologie / Archaeology}

BETTS, M.W., T.M. FRIESEN

2004 Quantifying hunter-gatherer intensification: a zooarchaeological case study from Arctic Canada, Journal of Anthropological Archaeology, 23(4): 357384.

BRINK, J.W.

2005 Inukshuk: Caribou drive lanes on southern Victoria Island, Nunavut, Canada, Arctic Anthropology, 42(1): 1-28.

FRIESEN, T. Max

2004 Contemporaneity of Dorset and Thule Cultures in the North American Arctic: New Radiocarbon Dates from Victoria Island, Nunavut, Current Anthropology, 45(5): 685-692.

MASCHNER, Herbert, Katherine REEDY-MASCHNER

2005 Aleuts and the sea, Archaeology, 58(2): 63-70. 
SAVELLE, J.M., J. HABU

2004 A processual investigation of a Thule whale bone house, Somerset Island, Arctic Canada, Arctic Anthropology, 41(2): 204-221.

STEWART, A.M., D. KEITH, J. SCOTTIE

2004 Caribou crossings and cultural meanings: Placing traditional knowledge and archaeology in context in an Inuit landscape, Journal of Archaeological Method and Theory, 11(2): 183-211.

WENZEL, George W., James M. SAVELLE

2004 Allen P. McCartney's contributions to Canadian archaeology: A photo essay, Arctic Anthropology, 41(2): 197-203.

WHITRIDGE, $P$.

2004 Landscapes, houses, bodies, things: "Place" and the archaeology of Inuit imaginaries Journal of Archaeological Method and Theory, 11(2): 213-250.

Art

CROSS, Dyan

2004 L'art du tissage, Revue de l'Impériale, 88(3): 4-9.

GRABURN, Nelson H.H.

2004 Authentic Inuit art: Creation and exclusion in the Canadian North, Journal of Material Culture, 9(2): 141-159.

KAINE, Elisabeth

2004 Des expériences communautaires de mises en exposition en territoire inuit, Anthropologie et sociétés, 28(2): 141-154.

McCALL, Sophie

2004 "I Can Only Sing This Song to Someone Who Understands It": Community Filmmaking and the Politics of Partial Translation in Atanarjuat, the Fast Runner, Essays on Canadian Writing, Fall 2004: 19.

WHITE, Jerry

2005 Frozen but Always in Motion: Arctic Film, Video, and Broadcast, Velvet Light Trap, Spring 2005: 52-65.

\section{Economie / Economy}

ASKEGAARD, S $\varnothing$ ren, Eric J. ARNOULD, Dannie KJELDGAARD

2005 Postassimilationist Ethnic Consumer Resions, Journal of Consumer Research, 32(1): 160-171. 
BETTS, M.W.

2005 Seven focal economies for six focal places: The development of economic diversity in the western Canadian Arctic, Arctic Anthropology, 42(1): 47-87.

CHABOT, Marcelle

2004 Consumption and standards of living of the Quebec inuit: Cultural permanence and discontinuities, Canadian Review of Sociology and Anthropology / Revue Canadienne de Sociologie et d'Anthropologie, 41(2): 147-170.

GOMBAY, Nicole

2005 The commoditization of country foods in Nunavik: A comparative assessment of its development, applications, and significance, Arctic, 58(2): $115-128$.

\section{Éducation / Education}

FULLER-THOMSON, Esme

2005 Canadian First Nations Grandparents Raising Grandchildren: A Portrait in Resilience, International Journal of Aging and Human Development, 60(4): 331-342.

ISEKE-BARNES, Judy M., Cory SAKAI

2003 Indigenous knowledges, representations of indigenous peoples on the Internet, and pedagogies in a case study in education: questioning using the Web to teach indigenous peoples [Exploring Nunavut], The Journal of Educational Thought, 37(2): 197.

MURRAY, R. Thomas

2003 Can money undo the past? A Canadian example, Comparative Education, 39(3): 331-344.

PRICE, Kimberly C.

2003 Teaching as learning in a Yup'ik Eskimo village, English Journal (High school edition), 93(2): 42-48.

WALKIE, Charles

2005 Qaneryaramta Egmiucia: Continuing Our Language, Anthropology \& Education Quarterly, 36(1): 107-111.

\section{Environnement / Environment}

ARMITAGE, D.R.

2005 Community-based Narwhal management in Nunavut, Canada: Change, uncertainty, and adaptation, Society \& Natural Resources, 18(8): 715-731. 
COTEL, A.J., R. GOLINGO, J.E. OAKES, R.R. RIEWE

2004 Effect of ancient Inuit fur parka ruffs on facial heat transfer, Climate Research, 26(1): 77-84.

GILCHRIST, G., M. MALLORY , F. MERKEL

2005 Can local ecological knowledge contribute to wildlife management? Case studies of migratory birds, Ecology and Society, 10(1): 20-31. [online] URL: http://www.ecologyandsociety.org/vol10/iss1/art20/

HERMANSON, Mark H., James R. BROZOWSKI

2005 History of Inuit Community Exposure to Lead, Cadmium, and Mercury in Sewage Lake Sediments, Environmental Health Perspectives, 113(10): 1308-1313.

\section{Histoire / History}

FRIESEN, T.M.

2004 Kitigaaryuit: A portrait of the Mackenzie Inuit in the 1890s, based on the journals of Isaac O. Stringer, Arctic Anthropology, 41(2): 222-237.

KENNEDY, Greg

2004 Stepping Stones to Nowhere: The Aleutian Islands, Alaska, and American Military Strategy, 1867-1945, Canadian Journal of History, 39(3): 634-636.

PALSSON, Gisli

2004 Race and the intimate in Arctic exploration, Ethnos, 69(3): 363-386.

\section{Linguistique / Linguistics}

PATRICK, Donna

2005 Language rights in indigenous communities: The case of the Inuit of Arctic Quebec, Journal of Sociolinguistics, 9(3): 369-389.

\section{Littérature / Literature}

BRADFORD, Clare

2003 "Oh how different!": Regimes of knowledge in aboriginal texts for children, The Lion and the Unicorn, 27(2): 199-218.

CREW, Hilary S.

2004 Mette Newth's The Abduction, The Transformation, and Arctic Colonialism: A Postcolonial Perspective, The Lion and the Unicorn, 28(3): 429-446. 
GRACE, S.

2004 Inuit journey: The co-operative venture Canada's North, Canadian Literature, 183: 153-155.

\section{Politique / Politics}

DOUBLEDAY, N., A. MACKENZIE, D. FIONA, S. DALBY

2004 Reimagining sustainable cultures: constitutions, land and art, Canadian Geographer, 48(4): 389-403.

HALLEY, Paule

2003 La protection juridique de la biodiversité et des activités d'exploitation faunique des Inuits du Nunavik, Cahiers de droit, 44(4): 691-747.

LÉTOURNEAU, Jean-François

2005 Modernité et autonomie politique: la lutte des Inuit du Nunavik, Globe: revue internationale d'études québécoises, 8(1): 37-48.

THOMPSON, Niobe

2004 Migration and Resettlement in Chukotka: A Research Note, Eurasian Geography and Economics, 45(1): 73-81.

\section{Santé / Health}

BJERREGAARD, P.

2005 Development of a public health programme in Greenland, Scandinavian Journal of Public Health, 33(4): 241-242.

BJERREGAARD, P., P. JOHANSEN, G. MULVAD, H.S. PEDERSEN, J.C. HANSEN

2004 Lead sources in human diet in Greenland, Environmental Health Perspectives, 112(15): 1496-1498.

BJERREGAARD, P., T.K. YOUNG , E. DEWAILLY, S.O.E. EBBESSON

2004 Indigenous health in the Arctic: an overview of the circumpolar Inuit population Scandinavian Journal Of Public Health, 32(5): 390-395.

BJORKSTEN, K.S., P. BJERREGAARD, D.F. KRIPKE

2005 Suicides in the midnight sun - a study of seasonality in suicides in West Greenland, Psychiatry Research, 133(2-3): 205-213.

BLISS, Rosalie Marion

2005 Nutrient Database to Help Native Communities, Agricultural Research, 53(9): 17-18. 
CHRISTOFIDES, Anna, Claudia SCHAUER, Stanley H. ZLOTKIN

2005 Iron Deficiency and Anemia Prevalence and Associated Etiologic Risk Factors in First Nations and Inuit Communities in Northern Ontario and Nunavut, Canadian Journal of Public Health, 96(4): 304-308.

DALLAIRE, Frédéric, Éric DEWAILLY, Gina MUCKLE, Carole VÉZINA et al. 2004 Acute Infections and Environmental Exposure to Organochlorines in Inuit Infants from Nunavik, Environmental Health Perspectives, 112(14): 13591365 .

EGELAND, Grace M., Peter BERTI, Rula SOUEIDA, Laura T. ARBOUR et al. 2004 Age Differences in Vitamin A Intake Among Canadian Inuit, Canadian Journal of Public Health, 95(6): 465-470.

FRIBORG, Jeppe, Anders KOCH, Flemming STENZ

2004 A Population-Based Registry Study of Infant Mortality in the Arctic: Greenland and Denmark, 1973-1997, American Journal of Public Health, 94(3): 452-457.

GOINS, R. Turner, S. Melinda SPENCER

2005 Public Health Issues Among Older American Indians and Alaska Natives, Generations, 29(2): 30-36.

HALDORSEN, T., TYNES T.

2005 Cancer in the Sami population of North Norway, 1970-1997, European Journal of Cancer Prevention, 14(1): $63-68$.

JOHANSEN, P., D. MUIR, G. ASMUND, F. RIGET

2004 Human exposure to contaminants in the traditional Greenland diet, Science of The Total Environment, 331(1-3): 189-206.

JORGENSEN, M.E., P. BJERREGAARD, F. GYNTELBERG et al.

2004 Prevalence of the metabolic syndrome among the Inuit in Greenland. A comparison between two proposed definitions, Diabetic Medicine 21(11): $1237-1242$.

KUHNLEIN, H. V., O. RECEVEUR, R. SOUEIDA , G. M. EGELAND

2004 Arctic Indigenous Peoples Experience the Nutrition Transition with Changing Dietary Patterns and Obesity1-3, The Journal of Nutrition, 134(6): 1447-1454.

NASH, David A., Ron J. NAGEL

2005 Confronting Oral Health Disparities Among American Indian/Alaska Native Children: The Pediatric Oral Health Therapist, American Journal of Public Health, 95(8): 1325-1330. 
NOBMANN, Elizabeth D., Rafael PONCE, Claudia MATTIL, Richard DEVEREUX et al.

2005 Dietary Intakes Vary with Age among Eskimo Adults of Northwest Alaska in the GOCADAN Study, 2000-2003(1-3), The Journal of Nutrition, 135(4): 856-863.

SCHNEIDER, Eileen

2005 Tuberculosis Among American Indians and Alaska Natives in the United States, 1993-2002, American Journal of Public Health, 95(5): 873-881.

STEENBEEK, Audrey

2004 Empowering health promotion: A holistic approach in preventing sexually transmitted infections among First Nations and Inuit adolescents in Canada, Journal of Holistic Nursing, 22(3): 254-266.

SUNDARAM, V., HELWEG-LARSEN K., LAURSEN B et al.

2004 Physical violence, self rated health, and morbidity: Is gender significant for victimisation?, Journal of Epidemiology and Community Health, 58(1): 6570 .

TESTER, Frank J., Paule McNICOLL

2004 Isumagijaksaq: mindful of the state: social constructions of Inuit suicide, Social Science \& Medicine, 58(12): 2625-2636.

WEBSTER, P.

2005 Health in the Arctic Circle, Lancet, 365(9461): 741-742.

WIND, Steven, David VAN SICKLE, Anne L. WRIGHT, 2004 Health, place and childhood asthma in southwest Alaska, Social Science \& Medicine, 58(1): 75-88.

\section{Savoir traditionnel / Traditional knowledge}

ELLIS, S.C.

2005 Meaningful consideration? A review of traditional knowledge in environmental decision making, Arctic, 58(1): 66-77. 